\title{
Some physico-chemical and biological characteristics of soil and water samples of part of the Niger Delta area, Nigeria
}

\section{PUYATE Y.T. ${ }^{1}$; RIM-RUKEH A. ${ }^{2}$}

\begin{abstract}
${ }^{1}$ Department of Chemical Engineering, Rivers State University of Science and Technology, Port Harcourt, P.M.B. 5080, Port-Harcourt, Nigeria. (E-mail: ytpuyate@yahoo.com). ${ }^{2}$ Department of Integrated Science, College of Education, P. M. B. 2090, Agbor, Delta State,
\end{abstract} Nigeria.

\begin{abstract}
Environmental conditions that influence biocorrosion in the Niger Delta area of Nigeria are investigated experimentally by analysing the physico-chemical and biological characteristics of four (4) soil samples and water samples taken from ten (10) selected river bodies in the region. Measured properties of the water samples and the corresponding results are $\mathrm{pH}(4.5$ to 6.5$)$, temperature $\left(26.9\right.$ to $\left.28.7^{\circ} \mathrm{C}\right)$, electrical conductivity ( 18.9 to $156.4 \mathrm{us} / \mathrm{cm}$ ), turbidity (19 to $48 \mathrm{NTU})$, redox potential $(-372$ to $+202 \mathrm{mV})$, TDS (78 to $8450 \mathrm{mg} / \mathrm{l})$, TOC (17.3 to $38.7 \mathrm{mg} / \mathrm{l})$, nitrate ions $(6.1$ to $17.0 \mathrm{mg} / \mathrm{l})$, sulphate ions $(0.8$ to $13.6 \mathrm{mg} / 1)$, DO $(4.1$ to $5.7 \mathrm{mg} / \mathrm{l})$, and microbial population $\left(10^{5}\right.$ to $\left.10^{6} \mathrm{cfu} / \mathrm{ml}\right)$, while those of the soil samples are water content (37 to $\left.51 \%\right)$, organic matter (9.4 to $18.9 \%$ dry weight), nitrate ions $(0.71$ to $1.82 \mathrm{mg} / \mathrm{l})$, sulphate ions $(2.1$ to $5.8 \mathrm{mg} / \mathrm{l})$ and microbial population $\left(10^{4}\right.$ to $10^{6} \mathrm{cfu} / \mathrm{g}$ ). It shown through comparison of experimental results with literature that the levels of the measured properties for both water and soil correspond to an environment that promotes biocorrosion. @ JASEM
\end{abstract}

Physico-chemical and biological interactions between a metallic material and its environment can lead to corrosion. The extent to which a corrosion process will proceed is determined by a number of factors (biotic or abiotic). The deterioration of a metal due to microbial activity (biological interaction) is generally termed microbiologically influenced corrosion (MIC) or biocorrosion. According to Videla (1996), biocorrosion is an electrochemical process where participation of microorganism is able to initiate, facilitate, or accelerate corrosion reaction without changing its electrochemical nature. Owing to its economic and environmental importance (Costerton and Boivin, 1991), microbiologically influenced corrosion has been the subject of extensive studies for the last three decades. Today, MIC has been reported in many systems, for example, underground pipelines (Harris, 1960), drilling operations (Abu, 1992), marine structures (Videla, 1996), cooling water systems (Mittelman, 2003), and waste water treatment facilities (Iversen, 2001). Bacteria are considered the primary colonizers of inanimate surfaces in both natural and man-made environments. The main types of bacteria associated with metallic corrosion in both terrestrial and aquatic habitats are Sulphate Reducing Bacteria (SRB), Iron Oxidizing Bacteria (IOB), Sulphur Oxidizing Bacteria (SOB), Manganese Oxidizing Bacteria (MOB), Nitrate Reducing Bacteria (NRB), and bacteria secreting organic acids and extra cellular polymeric substances (EPS) or slime (Characklis, 1981). The process of biocorrosion proceeds through a series of oxidation (anodic) and reduction (cathodic) reactions of chemical species in direct contact with or in close proximity to the metallic surface. Microorganisms add to the corrosion process all the diverse effects that influence the kinetics of the corrosion process of metals (Borenstein, 1991). The key factor that alters the conditions at a metal surface is the environment where the metal is located (Edyrean and Videla, 1991). In corrosion failure analysis (CFA), Videla (1996) and Stein (1995) suggested laboratory examination of the environment where the affected metal is located and the inorganic deposits on the corroded material. Stein (1995) observed that regions susceptible of biocorrosion would have the following characteristics (i) presence of dead legs, (ii) flow regime less than $1.5 \mathrm{~m} / \mathrm{s}$, (iii) continuous flow or stagnant, (iv) $\mathrm{pH}$ below 10.5 , and (v) temperature below $98.9^{\circ} \mathrm{C}$. In addition, Borenstein (1995) observed that the chemical composition of water environment that will not promote biocorrosion include (i) organic carbon $<1 \mathrm{mg} / \mathrm{l}$, (ii) hardness with $\mathrm{CaCO}_{3}>50 \mathrm{mg} / \mathrm{l}$, (iii) iron $<0.3 \mathrm{mg} / \mathrm{l}$, and (iv) sulphate ions $<1.0 \mathrm{mg} / \mathrm{l}$.

The petroleum industry in Nigeria has over the years experienced a number of corrosion problems. For example, between 1990 and 1999, the Nigeria Agip Oil Company (NAOC) reported 48 cases of petroleum production system failure due to corrosion (NAOC, 2004). The transportation of crude oil and gas in Nigeria from production area to distribution terminals is through pipelines that run through soil systems and water bodies. For the purpose of security and safety, all such pipelines are buried beneath the earth surface to a depth of about $1.1 \mathrm{~m}$. Literature on the environmental conditions in Niger Delta in relation to biocorrosion is very thin. The aim of this study is to determine the physico-chemical and biological characteristics of a cross-section of river waters and soil systems in Niger Delta, with a view to ascertaining the various environmental factors that initiate, promote, and sustain biocorrosion in the area. 


\section{STUDY AREA: NIGER DELTA}

The Niger Delta (see Fig. 1) is located within Latitudes $5^{0} 45^{\prime}$ and $6^{0} 35^{\prime}$, and longitudes $4^{0} 50^{\prime}$ and $5^{0} 15$, in the central part of Southern Nigeria and has a land mass covering some 70,000 square kilometers which accounts for about 8 percent of Nigeria's land mass (NDES, 2003). The ecology of the area is characterized by a vast flood plain built up by accumulation of sedimentary deposits washed down into the Niger and Benue Rivers. The area is crisscrossed with numerous rivers, streams, tributaries, creeks and creeklets. The vegetation of the area is characterized by (i) sandy coasts, ridge barriers, brackish or saline mangrove forest; (ii) fresh water swamp forest, and (ii) tropical rain forest. The area is the largest wetland in West Africa and one of the largest mangrove forests in the world (Darafeka, 2003). The geology of the Niger Delta area is such that the area comprises a lower unit (Akata formation, Eocene 600 to $6000 \mathrm{~m}$ thick), a middle unit
(Agbada formation, Eocene 300 to $4500 \mathrm{~m}$ thick) and an upper continental sequence of (Benin formation, Miocene 200 to $2000 \mathrm{~m}$ thick) (Akpokodje, 1987; Allen, 1965). Previous study (Gobo, 1998) of the meteorology of the area reveals an average atmospheric temperature of $25.5^{\circ} \mathrm{C}$ in the rainy season, and $30^{\circ} \mathrm{C}$ in the dry season. The daily relative humidity values range from 55.5 percent in the dry season to 96 percent in the rainy season. Rainfall in the area averages $2500 \mathrm{~mm}$ annually. The rainfall pattern shows two identifiable seasons: the rainy season (April to October) and a relatively short dry season (November to March). The Niger Delta is the home of the petroleum industry in Nigeria with distribution of onshore and offshore oil fields. It is estimated that Nigeria earns over 90 percent of its foreign exchange and over 80 percent of government revenues from the oil industry (Okoko and Nna, 1998).

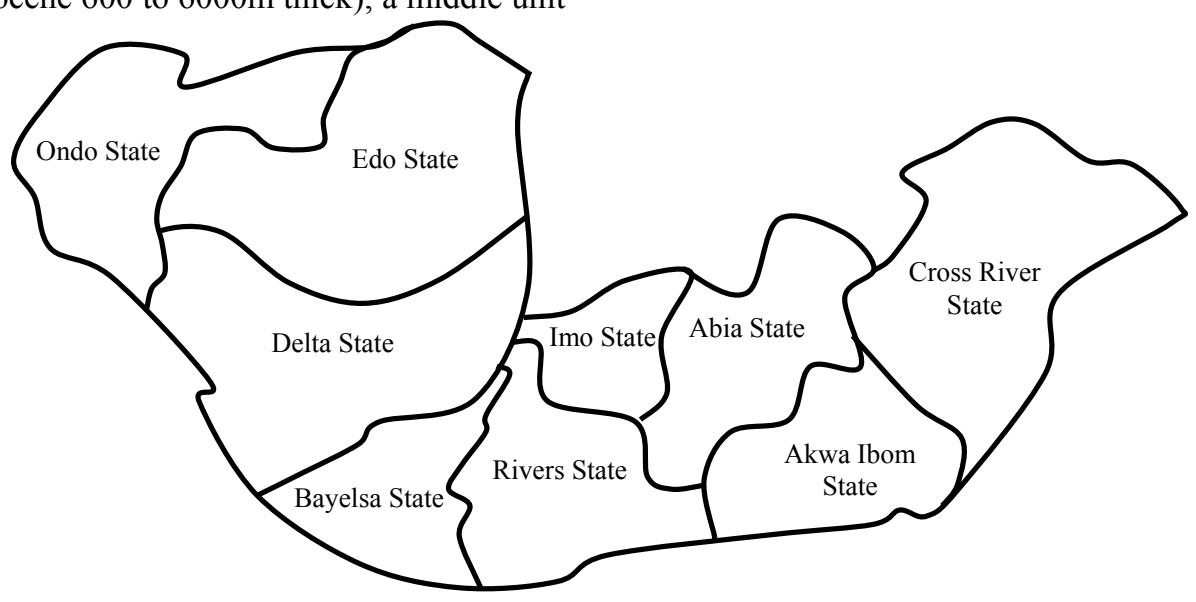

Fig. 1. Geopolitical map of the Niger Delta region.

\section{MATERIALS AND METHOD} Sample selection and collection

Ten river bodies and four soil samples were chosen for the study. The rivers selected are (1) Orashi River at Ebocha Well 8 Location, (2) Brass River at Brass Terminal jetty, (3) New Calabar River at Wilbros Nig. Ltd., (4) Apoi Creek at Ogbainbiri Flow Station, (5) Dodo Creek at Clough Creek Flow Station, (6) Sangana River at Igbomatoru Community, (7) Nun River at Tebidaba Flow Station, (8) Forcados River at Beniboye Flow Station, (9) Niger River at Independent Power Plant (IPP), and (10) Olagoga Creek at Obama Flow Station. Along the length of the selected river bodies, a site each was chosen for water sample collection. The choice of sites for collection of water samples was based on (i) history of corrosion failure, ( ii ) vicinity of industrial activities, (iii) and flow region with speed less than $1.5 \mathrm{~m} / \mathrm{s}$, and (iv) presence of humic substances. These characteristics are consistent with those identified for assessing microbiologically influenced corrosion problems (Stein, 1995). Water samples were collected in plastic containers pre-treated by washing them with $0.1 \mathrm{M}$ dilute hydrochloric acid and sundried. At each sample collection point, the plastic containers were first of all rinsed with the water to be collected. One container at a time, with its lid closed was then dipped into the water body to a depth of about $1.0 \mathrm{~m}$ and the lid removed to fill the container with water. The lid was replaced immediately, and the container with the water sample taken out of the water body. (Replacing the lid of the container at the sampled depth excludes air and prevents contamination of the water sample with microorganisms from the environment). Samples for microbial analysis were collected in sterilized McCartney glass bottles and stored in an ice-chest. All water samples were transported immediately to the laboratory for analysis. The four locations from which soil samples used for the study were collected are (i) 14" Obrikom-Ebocha pipeline at Ebocha well 
8, (ii) Okpai well 9 Location, (iii) 24" Ogada-Brass pipeline at Kalabile-Ama, and (iv) 14" ST pipeline at Beniboye Flow Station. Soil samples were collected at a depth of about $1.1 \mathrm{~m}$ from each of the study locations. Soil samples for microbial analysis were collected in sterilized McCartney glass bottles and stored in an ice-chest, while those for physicochemical analysis were collected in polyethylene bags. All soil samples were transported immediately to the laboratory for analysis.

\section{Experimental method}

All water samples were analysed for $\mathrm{pH}$, temperature, turbidity, redox potential, electrical conductivity, total organic carbon (TOC), dissolved oxygen (DO), total dissolved solids (TDS), nitrate ions $\left(\mathrm{NO}_{3}{ }^{-}\right)$, sulphate ions $\left(\mathrm{SO}_{4}{ }^{2-}\right)$, and total microbial count (TMC), while soil samples were analysed for $\mathrm{pH}$, organic matter, redox potential, nitrate ions $\left(\mathrm{NO}_{3}{ }^{-}\right)$, sulphate ions $\left(\mathrm{SO}_{4}{ }^{2-}\right)$, water content, and total microbial count. These parameters are good environmental impact indicators for microbiologically influenced corrosion problems (Videla, 1996; Stein, 1995). pH, electrical conductivity, DO, TDS, temperature, and turbidity were determined in-situ using a multi-parameter water quality monitor (Model 6000UPG). During determination of any of the parameters, the instrument was properly checked and calibrated before and after use. Redox potential of the samples was also determined in-situ using Orion multimeter (Model 1260) and combined platinum/silver electrodes. $\mathrm{SO}_{4}{ }^{2}$ and $\mathrm{NO}^{3-}$ were determined using turbidometric and ultraviolet spectrophotometer methods respectively. TOC was determined using an automated TOC analyzer (ESML 690), water content of soil samples was determined using weight loss technique, while TMC was determined using the rapid agar dipstick method. All methods of analysis are consistent with APHA (1992) and DPR (2002) standards.

\section{RESULTS AND DISCUSSION}

\section{Soil Analysis}

The results for the analysis of soil samples from the study are presented in Table 1 . The soil samples are clayey in nature, and the characteristic properties of soil in the Niger Delta region are well documented (Rahaman, 1976; Omorodion, 1988).

Table 1. Measured parameters of soil samples in the study area.

\begin{tabular}{|c|c|c|c|c|c|c|c|}
\hline \multirow[t]{2}{*}{ Location } & \multicolumn{7}{|c|}{ Parameters } \\
\hline & $\mathrm{pH}$ & $\begin{array}{l}\text { Organic matter } \\
(\% \text { dry wt. })\end{array}$ & Eh $(\mathrm{mV})$ & $\begin{array}{c}\mathrm{H}_{2} \mathrm{O} \text { content } \\
(\%)\end{array}$ & $\begin{array}{l}\mathrm{NO}_{3}^{-} \\
(\mathrm{mg} / \mathrm{l})\end{array}$ & $\begin{array}{l}\mathrm{SO}_{4}^{2-} \\
(\mathrm{mg} / \mathrm{l})\end{array}$ & $\begin{array}{l}\text { Microbial count } \\
(\mathrm{cfu} / \mathrm{g})\end{array}$ \\
\hline $\begin{array}{l}\text { 14" Pipeline at Ebocha } \\
\text { Well } 8\end{array}$ & 5.6 & 17.5 & -80 & 43 & 0.71 & 4.61 & $10^{6}$ \\
\hline Okpai Well 9 & 5.8 & 9.4 & -95 & 37 & 1.82 & 4.7 & $10^{4}$ \\
\hline $\begin{array}{l}\text { 24" Pipeline at Kalabile- } \\
\text { Ama }\end{array}$ & 6.1 & 18.9 & -115 & 49 & 0.98 & 2.10 & $10^{5}$ \\
\hline $\begin{array}{l}\text { 14" Pipeline at Beniboye } \\
\text { Flow Station }\end{array}$ & 5.2 & 18.3 & -87 & 51 & 1.02 & 5.80 & $10^{6}$ \\
\hline
\end{tabular}

The results indicate that the soil in the region is acidic as the $\mathrm{pH}$ of all soil samples lie within a range from 5.2 to 6.2 , which is consistent with the range (4.5 to 9) specified by Costerton et al. (1995) for microbial activity to take place, though it is argued by Harris (1960) that $\mathrm{pH}$ within a range from 5 to 9 has no effect on corrosion. The high water content in all soil samples (37\% to $51 \%$ ) may be attributed to ground water level, precipitation, and permeability of the soil. It has been found that pipeline ditch is a favourable environment for bacteria because trench backfill does not consolidate to a great degree as an undisturbed soil even after many years (Harris, 1960). This tends to permit easier penetration of water throughout the backfill. This probably explains the higher water content in soil samples collected along pipeline route than those collected at undisturbed location. In addition, pipeline ditch has high affinity for air which makes it suitable for development of aerobic bacteria. A key feature that initiates and promotes biocorrosion is water or an aqueous phase. Thus water is the main requirement for microbial life and also for corrosion to occur (EPA, 1992). The redox potential (Eh) of all soil samples ranges from $-80 \mathrm{mV}$ to $-115 \mathrm{mV}$, indicating a reducing environment. A negative redox potential indicates corrosive environment (Booth, 1971). The levels of organic matter, $\mathrm{NO}_{3}^{-}$, and $\mathrm{SO}_{4}^{2-}$, in all soil samples analysed vary from 9.4 to 18.9 (\% dry wt.), 0.71 to $1.82 \mathrm{mg} / \mathrm{l}$, and 2.1 to $5.8 \mathrm{mg} / \mathrm{l}$ respectively. Organic materials of any type are suitable foodstuffs for bacteria growth. Adequate supply of nitrate and sulphate are essential for increased activity of microorganisms since nitrogen, sulphur, and carbon are essential elements for cellular metabolism in microbial life. The high population of bacterial count in the soil samples $\left(10^{4}\right.$ and $\left.10^{6} \mathrm{cfu} / \mathrm{g}\right)$ is an indication of availability of good food supply. In addition, pipeline coating materials are suitable for bacteria growth (Harris, 1960) which probably explains the higher population count along pipeline route than at well location. Microbial population between $10^{4}$ and $10^{6} \mathrm{cfu} / \mathrm{g}$ in soil sample is an indication of corrosion problem (Costello, 1969). 


\section{Water Analysis}

The $\mathrm{pH}$ of all water samples in Fig. 2 ranges from 5.4 to 6.5 , indicating an acidic medium. Acidic environment with $\mathrm{pH}<6$ or alkaline environment with $\mathrm{pH}>8$ is more corrosive than an environment with $\mathrm{pH}$ values from 6 to 8 (Bradford, 1993). The acidic $\mathrm{pH}$ may have resulted from humic acid (HA) formed from decaying organic matter (leaves), which is consistent with the report of the Niger Delta swamp environment (RPI, 1995) where observed $\mathrm{pH}$ values in the acidic domain were attributed to the presence of humic acid. The $\mathrm{pH}$ values of the water samples also lie within a range from 4 to 9 identified by Costerton et al. (1995) to be suitable for bacteria growth. The locations with the highest and lowest $\mathrm{pH}$ values are Apoi Creek by Ogbainbiri Flow Station and Brass River by Brass terminal Jetty respectively. Figure 3 shows the temperature range of the water samples from the various locations (i.e. $26.9^{\circ} \mathrm{C}$ to $28.7^{\circ} \mathrm{C}$ ), which is suitable for bacteria growth (optimal temperature for bacteria growth lies between $25^{\circ} \mathrm{C}$ and $30^{\circ} \mathrm{C}$ (Booth, 1971)). The water sample collected from Apoi Creek by Ogbainbiri Flow Station has the highest temperature value of $28.7^{\circ} \mathrm{C}$, while that collected from Orashi River by Ebocha Well 8 Location has the lowest temperature of $26.9^{\circ} \mathrm{C}$. Electrical conductivity of the water samples ranges from $18.9 \mu \mathrm{s} / \mathrm{cm}$ to $156.4 \mu \mathrm{s} / \mathrm{cm}$, indicating the presence of ions in the water bodies. Variation of electrical conductivity across all sample locations is illustrated graphically in Fig. 4. The sample with the highest conductivity value of $156.4 \mu \mathrm{s} / \mathrm{cm}$ was that collected from Forcados River by Beniboye Flow
Station, and is closely followed by that collected from Brass River by Brass Terminal jetty with a value of $129.8 \mu \mathrm{s} / \mathrm{cm}$. These high electrical conductivity values may have resulted from seawater intrusion, as observed for Warri River sample collected at Warri Refinery and Petrochemical Company (WRPC), Effurun (Egborge, 1994). The sample with the lowest value of electrical conductivity $(18.9 \mu \mathrm{s} / \mathrm{cm})$ was collected from Niger River by Independent Power Plant, Okpai, Delta State. Turbidity values of all water samples range from 19 NTU to 48 NTU. The relatively high values of turbidity for all samples may be the result of both suspended and dissolved solids in the water (see Fig. 5). Redox potential (Eh) of all water samples lie within a range from $-372 \mathrm{mV}$ to $+202 \mathrm{mV}$ as illustrated graphically in Fig.6. Spectrum of redox potential under which microbial life can be found ranges from $-450 \mathrm{mV}$ to $+850 \mathrm{mV}$, where the negative side of the spectrum favours methanogenic bacteria, and the positive side corresponds to iron bacteria (Newman et al., 1991). Thus, the positive redox potential values obtained for samples collected from Forcados River by Beniboye Flow Station and New Calabar River by Wilbross (Nig) Ltd indicate the presence of iron oxidizing bacteria. The water sample with the most negative redox potential $(-372 \mathrm{mV})$ was that collected from Sangana River by Igbomatoru, indicating the most corrosive environment. The water sample with the highest redox potential $(+202 \mathrm{mV})$ was that collected from Forcados River by Beniboye Flow Station, with minimum contribution to corrosion.

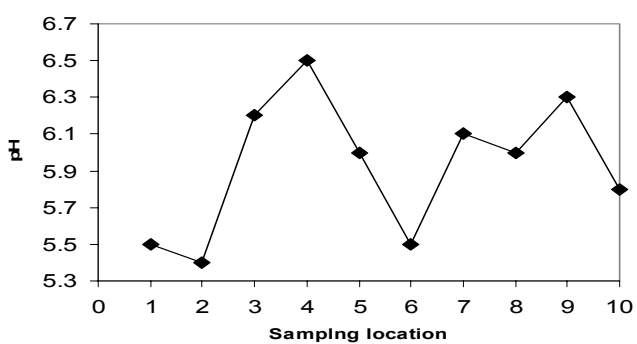

Fig.2. Variation of $\mathrm{pH}$ across all sample locations.

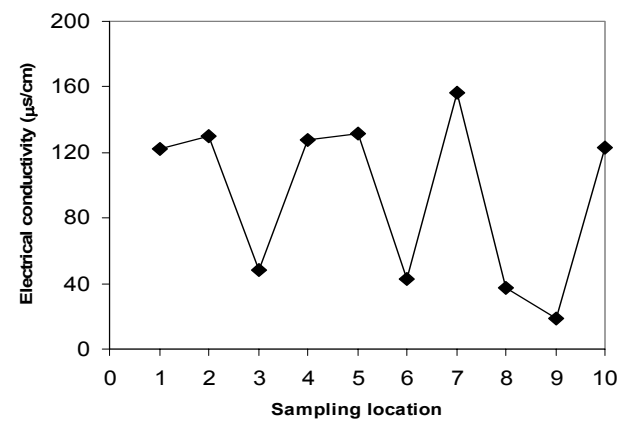

Fig. 4. Variation of Electrical Conductivity across all sample locations.

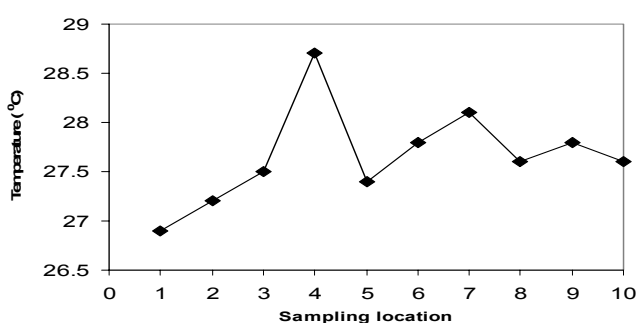

Fig.3. Variation of Temperature across all sample locations.

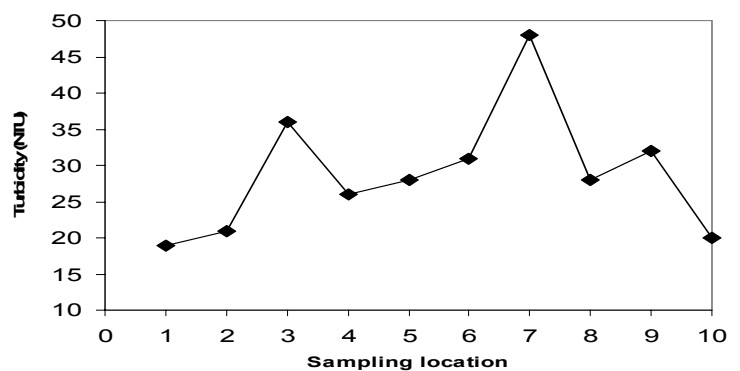

Fig. 5. Variation of Turbidity across all sample locations. 

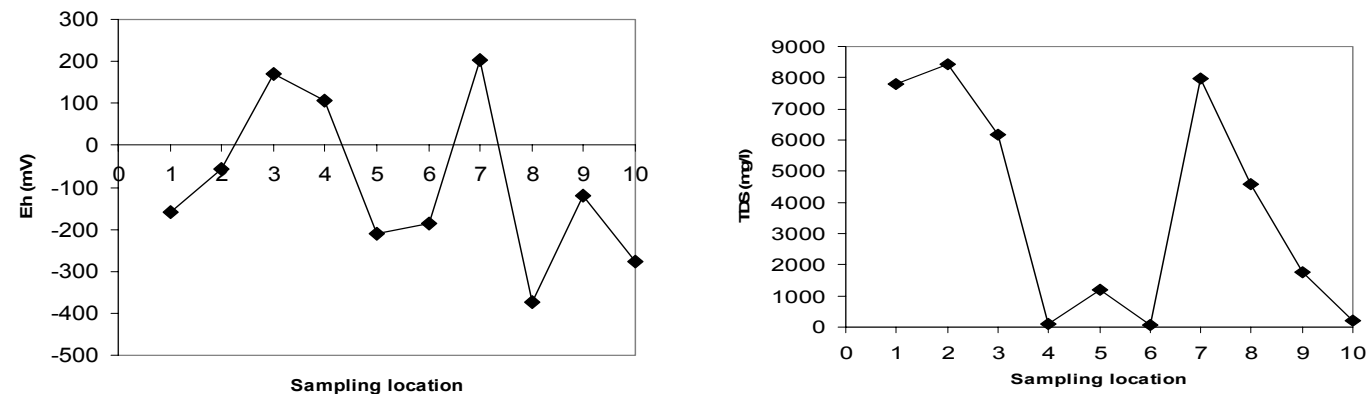

Fig. 6. Variation of Eh across all sample locations.

Fig.7. Variation of TDS across all sample locations.
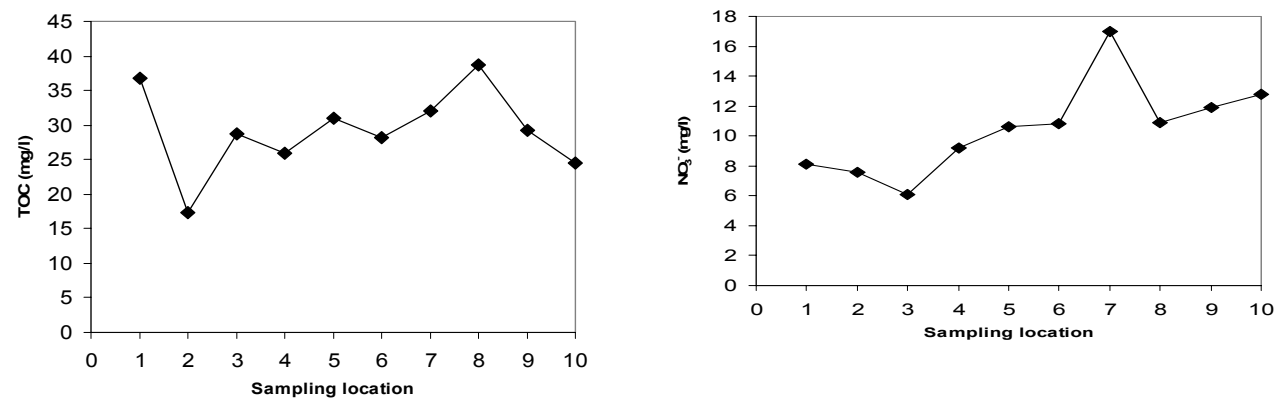

Fig. 8. Variation of TOC across all sample locations.

Fig.9. Variation of $\mathrm{NO}_{3}^{-}$across all sample locations.
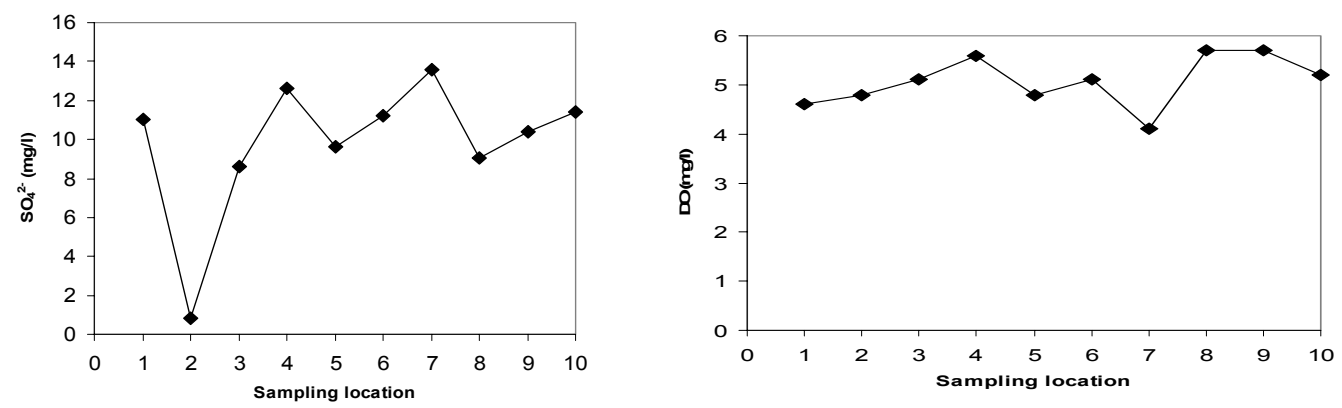

Fig.10. Variation of $\mathrm{SO}_{4}{ }^{2-}$ across all sample locations.

Fig. 11. Variation of DO across all sample locations.

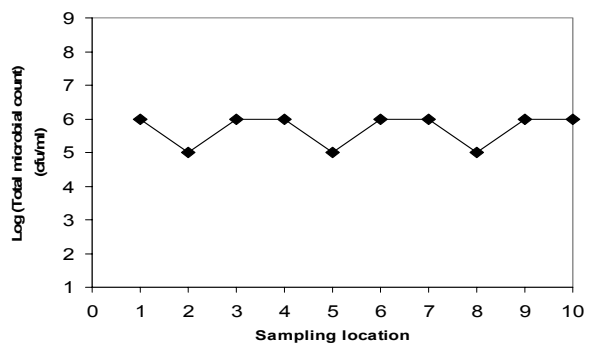

Fig. 12. Total Microbial Count across all sample locations.

Variations of TDS and TOC in all water samples analysed are illustrated graphically in Figs. 7 and 8 respectively. The level of TDS in all samples ranges from $78 \mathrm{mg} / 1$ to $8450 \mathrm{mg} / \mathrm{l}$, while that of TOC lies within a range from $17.3 \mathrm{mg} / \mathrm{l}$ to $38.7 \mathrm{mg} / \mathrm{l}$. Carbon is the most abundant cell constituent, and can be obtained from organic matter (Videla, 1996). The river environment in the study area provides an excellent condition for bacteria growth because of the high levels of TDS and TOC. Water sample collected from Brass River at Brass Terminal jetty has the highest value of TDS $(8450 \mathrm{mg} / \mathrm{l})$, while that collected from Nun River at Tebidaba Flow Station has the lowest value of TDS $(78 \mathrm{mg} / \mathrm{l})$. This wide 
difference in TDS values may be attributed to the levels of industrial activity at Brass Terminal and Tebidaba Flow Station, which is higher in the former than the latter. Water sample collected from Sangana River at Igbomatoru has the highest value of TOC $(38.7 \mathrm{mg} / \mathrm{l})$, while that collected from Brass River at Brass Terminal jetty has the lowest value of TOC $(17.3 \mathrm{mg} / \mathrm{l})$. The concentration of nitrate ions $\left(\mathrm{NO}_{3}{ }^{-}\right)$ in all water samples varies from $6.1 \mathrm{mg} / 1$ to $17.0 \mathrm{mg} / 1$, while that of sulphate ions $\left(\mathrm{SO}_{4}{ }^{2-}\right)$ varies from $0.8 \mathrm{mg} / 1$ to $13.6 \mathrm{mg} / \mathrm{l}$. There must be adequate supply of nutrients for synthesis of new cells and generation of energy in any aquatic environment that sustains bacteria growth. Nitrogen, sulphur, and phosphorus are essential complements for carbon, hydrogen, and oxygen in cell metabolism, with many bacteria obtaining their nitrogen and sulphur requirement from nitrates and sulphates respectively (EPA, 1992). Lack of these elements limits growth and activity of microorganisms, whereas their abundance results in uncontrolled microbial growth. Variation patterns of these nutrients in all water samples analysed are illustrated graphically in Figs. 9 and 10. Dissolved oxygen in all water samples ranges from $4.1 \mathrm{mg} / 1$ to $5.7 \mathrm{mg} / \mathrm{l}$, indicating an environment that promotes growth of aerobic microorganisms. The level of oxygen in an environment plays an important role in corrosion process especially where oxygen reduction is generally the main cathodic reaction. Variation of DO in the water samples analysed is shown in Fig. 11. The narrow variation of DO of all water samples suggests that the aquatic environment promotes the existence of facultative organisms. Bacterial population varies from $10^{5} \mathrm{cfu} / \mathrm{ml}$ to $10^{6} \mathrm{cfu} / \mathrm{ml}$ in all water samples analysed, indicating adequate bacterial population for biocorrosion activity. It has been suggested that Sulphate Reducing Bacteria (SRB) level of $10^{4}$ cells $/ \mathrm{cm}^{3}$ is a clear indication of possible corrosion problem, while a relative population of $10^{6}$ cells $/ \mathrm{cm}^{3}$ of microorganisms is a concern of potential corrosion problem in an environment (Costello, 1969). The total microbial count in all samples fluctuates between $10^{5}$ and $10^{6}$ cells $/ \mathrm{cm}^{3}$ as shown in Fig .12.

Conclusion: Physico-chemical and biological characteristics of water and soil samples collected in the Niger Delta region have been presented. It is shown that the levels of measured parameters in both water and soil samples are consistent with the conditions in an environment that favours microbial activity. The Niger Delta, therefore, exhibits the necessary qualities for promotion and sustenance of biocorrosion.

\section{REFERENCES}

Abu, G. O. (1992). Biotechnological and physicochemical strategies on the monitoring and control of biocorrosion due to sulphate reducing bacteria activities in petroleum production systems, NICA/ICON/PAPER 1/92/6.

Akpokodje, E. G. (1987). The engineering geological characteristics and classification of the major superficial soils of the Niger Delta, Engineering Geology, 23, 193-211.

Allen, J. R. (1965). Late quaternary of the Niger Delta and adjacent Areas: Sedimentary environments and lithofacies, AAPG BULL, 49, 547.

APHA (1992). American Public Health Association: Standard methods for the examination water and wastewater, $18^{\text {th }}$ ed., Washington D.C.

Borenstein, S. W. (1991). Why does microbiologically influenced corrosion occur at or adjacent to austenitic stainless steel weldments? Corrosion/91: Paper No. 286, NACE International, Houston, Texas.

Booth, G. H. (1971). Microbiological corrosion, London: Mills and Boon Limited, 27-29.

Bradford, S. A. (1993). Corrosion Controls, New York: Van Nostrand Reinhold.

Characklis, W. G. (1981). Fouling biofilm development: A process analysis, Biotechnology and Bioengineering, 23, 1923 - 1929.

Costello, J. A. (1969). The corrosion of metals by microorganisms: A literature survey, International Biodeterioration Bulletin, 5, 101106.

Costerton, J. W. and Boivin, J. (1991). Economics of microbial corrosion in water systems, International Congress on Microbially Influenced Corrosion, Knoxville.

Costerton, J. W., Lewandowski, Z., Coldwell, D. E., Korber, D. R. and Lappin-Scott, H. M. (1995). Microbial biofilms. Annual Review of Microbiology, 49, 711-745.

Darefeka, M. D. (2003). Water quality standards and guidelines in Nigeria, Paper presented at the $2^{\text {nd }}$ Conference on Water, Port Harcourt, Rivers State. 
DPR (2002). Department of Petroleum Resources: Environmental guidelines and standards for the petroleum industry in Nigeria, Lagos: Government Press.

EPA (1992). Environmental Protection Agency: Seminar publication on the control of biofilm growth in drinking water distribution systems, EPA/625/R-92/001.

Edyrean, R. G. J. and Videla, H. A. (1991). Biological corrosion, Inter disciplinary Science Review, 16 (3), 267-271.

Egborge, A. B. M. (1994). Water Pollution in Nigeria-Biodiversity and Chemistry of Warri River, Benin-City: Ben Miller Books (Nig) Ltd.

Gobo, A. E. (1998). Meteorology and Man's Environment, Ibadan: African-Link Books.

Harris, J. O. (1960). Soil microorganisms in relation to cathodically protected pipe, Corrosion, 16, 441-448.

Iversen, A. (2001). Microbially influenced corrosion on stainless steels in wastewater treatment plants: Part 1, British Corrosion Journal, 36 (4), 277-283.

Mittelman, M. (2003). Microbially influenced corrosion of sprinkler piping, Corrosion, 49, 13-17.

NAOC (2004). Nigerian Agip Oil Company: Oil Spill Statistics from 1990-2004.
NDES (2003). Niger Delta Environmental Survey: Phase 1 - Report on the Niger Delta Environment, 1-4.

Newman, R. C., Webester, B. J. and Kelly, R. G. (1991). The electrochemistry of SRB corrosion and related inorganic phenomena. ISIJ International, 31, 201-204.

Omorodion, K. (1988). Use of clay in wastewater treatment. B.Sc Project work, Department of Chemistry, University of Benin, Benin City, Nigeria.

Okoko, K. A. B. and Nna, J. N. (1998). Emerging trends and community perception in the Nigerian oil industry, Nigerian Journal of Oil and Politics, 1(7), 44-55.

Rahaman, M. A. (1976). Review of the basement geology of Southwestern Nigeria: In Geology of Nigeria, edited by Kogbe, C. A., Lagos: Elezabetha Publishing Company.

RPI (1995). Research planning institute: Environmental baseline studies for the establishment of control criteria and standards against petroleum related pollution in Nigeria, NNPC, Lagos.

Stein, A. A. (1995). MIC treatment and prevention: In A Practical Manual on MIC, edited by Kobrin, G., NACE International, Houston, Texas.

Videla, H. A. (1996). Manual of Biocorrosion, Florida: CRC Lewis Publishers. 